\title{
ARTICLES
}

\section{PRINCIPLES AND PHILOSOPHY OF PUNISHMENT IN ISLAMIC LAW, WITH SPECIAL REFERENCE TO MALAYSIA}

\author{
Mohammad Hashim Kamali*
}

\begin{abstract}
This article advances the theme that the conventional fiqhi articulations of the prescribed hudud punishments show inconsistency with the Qur'an and are, therefore, due for a corrective. Whereas the Qur'an makes repentance (tawbah) and reform (islah) integral to the hudud punishments, the fiqh expositions of these punishments have entirely ignored that aspect of the Qur'an. To carry out this corrective and rectify the hudud theory in the way it is suggested below partakes, we believe, in veritable ijtihad that Muslim jurists and jurisdictions are strongly advised to undertake and implement.
\end{abstract}

Keywords: Qur'an, Sunnah, justice, punishment, figh, repentance, reform.

\section{Introductory Remarks}

Islam is not a stranger to change and has internal mechanisms for how to both accommodate, and accept change, or provide a justified response. The need for fresh evaluation and recourse to the resources of ijtihad (independent reasoning), renewal (tajdid), and reform (islah) has been particularly felt in certain areas of the law more than others. Broadly, Muslim scholars and jurists were more active in applying these instruments in the sphere of private laws, such as marriage, divorce and inheritance, but not so in the spheres of public law, politics and good governance, and also criminal law, where ijtihad and tajdid were not effectively utilised and gaps developed between the shariah and social reality. This may explain why contemporary Islamic scholarship is faced with greater challenges for healthy adjustment and reform. Islamic criminal law has resisted adjustment due to the long-standing hold of imitation (taqlid), attitudes and perceptions that still prevail among Muslims within and outside Malaysia.

A discursive review and appraisal of Islamic punishments is called for due partly to internal factors, most notably the way Muslims have understood the 
hudud punishments, but also external challenges brought by globalisation and the contemporary human rights discourse. Malaysia is also signatory to many international human rights instruments that add emphasis to innovative interpretation and ijtihad. How Muslim countries and jurisdictions present their penal laws to the outside world is not altogether irrelevant. It is a matter of concern to Islamic civilisation, its claim to universality and inclusiveness, its commitment to justice, and its inner resources to accommodate the changing needs of Muslim society to show that efforts are being made to make necessary adjustments.

\section{Hudud in the Qur'an and Sunnah}

It is instructive to note that hudud, although commonly known as a set of quantitatively fixed punishments, does not carry that meaning. The word also does not occur in the Qur'an on its own but as part of the phrase hudud Allah (lit. God's limits) that occurs fourteen times in the Holy Book in the typical sense of signifying the 'limits', whether moral or legal, of acceptable behaviour from that which is unacceptable - for instance of separating the halal and haram (lawful and unlawful) from one another. On no occasion has the Qur'an, however, used hudud in the sense specifically of punishments, fixed or otherwise. The fact that hudud later began to signify fixed and mandatory punishments is a juristic terminology and addition, although it may arguably have some origins in the Sunnah, as discussed below. Punishment also signifies a limit and can as such be subsumed within the meaning of hudud Allah. The idea of 'limit' is thus basic both to the literal meaning and the Qur'anic usage of hudud, which is in one way or another reflected in all of the other usages of this term.

When the Qur'anic usage of hudud (in the sense of limits) is compared with its usage in fiqh manuals, one notices that a basic development has taken place, which is that hudud has been used to signify fixed and unchangeable punishments that have been laid down in the Qur'an or Sunnah. The concept of hudud in the Qur'an in the sense generally of 'separating or preventing' limits was thereby replaced by the very specific idea of fixed and mandatory punishments. ${ }^{1}$

Hudud Allah also occurs in the Sunnah but it is not clear whether it is used in the sense only of a certain number of specified offences. It is most likely used in the Sunnah as a reference to all offenses as violations of 'God's limits'. Juristic thought has, however, followed a different trajectory whereby this broader view of the hudud Allah was reduced to mean mandatory and fixed punishments.

The Qur'an has stipulated punishments for four offences, namely adultery and fornication (al-Nur, 24:2), theft (al-Ma'idah, 5:38-39), slanderous accusation 
(24:4), and highway robbery (5:33). Yet the fiqhi presentations of hudud increased these first to six, adding wine drinking and apostasy, and then to seven, adding armed rebellion. The Qur'an condemns these last three as heinous behaviours which must be avoided but provides no punishment for them. This was rather done in the face of clear shariah evidence that advised a minimalist rather than maximalist approach in crimes and punishments. Modern criminal law and jurisprudence also advise a restrictive approach to punishments. Moreover, whereas the Qur'an has, in all the four instances that specify punishments, also mentioned repentance and reform (tawbah and islah), juristic doctrine has either left this out altogether or reduced it to a mechanical formality, such as three days in the case of apostasy, in which the offender is given an opportunity to repent, failing which he is executed. This can hardly be said to be reflective of the original teachings of the Qur'an that clearly and unequivocally open the hudud to the prospects of repentance and reform.

Of the fourteen instances where 'hudud Allah' occurs in the Qur'an, no less than six occur in just one passage (al-Baqarah, 2:229-30) on the subject of marriage and divorce, none of which refer to a punishment. The married couple are thus advised to observe the hudud Allah in treating one another, and those who are unjust, commit oppression, and transgress the hudud Allah, they are the evildoers. The text continues to invite the people who know to understand and reflect on hudud Allah. The basic concern of hudud Allah in the Qur'an, here and elsewhere, is with the moral limits of conduct in the sense of identifying what is generally good and righteous, and what transgresses the limits of acceptable behaviour.

The following hadith is also instructive on how the Prophet understood the hudud. Wathilah ibn al-Asqa' has narrated that:

I was with the Messenger of God, pbuh, when a man came to him saying "O God's Messenger! I have committed a violation of the hudud Allah." The Prophet turned away from him. Then he asked again, and the Prophet turned away from him, then he said the same to the Prophet a third time, and again the Prophet turned away. Then it was time for prayer. When the prayer ended, the man told the Prophet a fourth time that he had committed a hadd of the hudud Allah God had prohibited, so apply to me God's punishment. The Prophet then said to him: "Did you not do your ablution well - for you prayed with us just now! Go away, that is your expiation."2 
According to another hadith:

'Aishah reported that the Prophet, pbuh, said: "Avoid condemning the Muslims to hudud (probably meaning punishments) whenever you can, in all instances of doubt, and when you can find a way out for a Muslim, then clear his way. If the Imam errs, it is better that he errs on the side of forgiveness than on the side of punishment."3

While criminality continues to threaten the fabric of society and civilisation almost everywhere, there is no compelling argument to confine prescribed punishments only to a handful of specified crimes. The changing conditions of society never cease to generate new problems and new opportunities for crime. New modes of criminality, often no less of a threat to society than the hudud crimes, have been on the increase. Would it not be justified then, to classify irresponsible dumping of industrial waste and radioactive pollutants, drug trafficking, human trafficking, and cyber crimes etc., as violations also of the hudud Allah or of God's limits and vital interests of the community! These may even be seen as far more serious perhaps than some of the traditional hudud offences such as drinking and slander.

The Qur'an has admittedly stipulated punishments for a small number of offences, but it was most likely not the Qur'an's intention to confine the hudud Allah to these offences nor to suggest hudud Allah as an offence category as such. There was no reason why the limits of God/hudud Allah should not have retained its general meaning as a basic philosophy of punishment that was reflective of the broader understanding of the Qur'anic outlook. To say that hudud are offences that are not open to repentance after they are reported to the authorities, and thereby close the door to the whole idea of rehabilitation and reform, marked the beginning of a basic imbalance. Yet juristic thought hardly looked back to rectify it in line with subsequent developments. If the Prophet had issued certain instructions that specified a number of crimes to be prosecuted once they were brought to his attention, this too was most likely intended to emphasise the rule of law vis-a-vis the all-too pervasive tribal power than to establish rigidities of the kind that had no place in the Qur'anic concept of hudud Allah. The Prophet was most likely concerned with establishing his leadership role, at a time when crimes and punishments were dominated by tribal practices, to say that these are the limits - once an offence has been reported to him, tribal interference must cease as of that time. This understanding is not only absent in the fiqh literature on hudud, but also made to mean that after reporting to the authorities, the hudud must be enforced, that the judge has no discretion in the matter other than ordering the punishment upon proof. The judge may not, in other words, consider 
the conditions of the offender, nor the possibility and relevance of repentance and reform. This is, in our view, alien to what the Prophet had meant, and it is no less than an unwarranted rigidity injected into the more open understanding of hudud in the Qur'an and Sunnah.

Within the general framework of hudud Allah, the Qur'an then expounds a set of broader guidelines for a comprehensive approach to punishment, which is inclusive of retribution, rehabilitation and reform. Thus it is provided in one place that punishment must be commensurate to the suffering inflicted in the first place "But one who forgives and reconciles, his reward is with God, for God loves not the transgressors." ${ }^{4}$ Also that crime is strictly an individual matter in that "No one carries the burden of another." This was revealed in view of the widespread tribalist practice that would punish not only the offender but also members of his family and tribe. The Qur'an further enjoined patience and forgiveness on the part of both the victim and the judge. Punishment severity and firmness in its application is always to be moderated by the demand for justice and fairness (al-' 'adl wa'l-ihsan). ${ }^{6}$ The basic approach to punishment is further expounded in such terms: "and if you decide to punish, then punish with the like of that with which you were afflicted. But if you show patience, that is indeed the best (course) for those who remain patient." ${ }^{\prime 7}$ Patience ( $\left.s a b r\right)$ in this verse can either mean a reflective pause that delays hasty conclusions, and hasty infliction of punishment, or abstaining from rash decisions by the authorities so as to allow time for reflection and the possibility of repentance, pardoning and reform.

Then also the following three Qur'anic verses on repentance and reform provide cogent considerations for the construction of a new and more comprehensive Islamic theory of punishment. The following three passages are self-explanatory and concise: 1) "But he who repents after his crime and amends his conduct, God turns to him in forgiveness. For God is Most Forgiving, Most Merciful;" 2) "Repentance with God is only for those who do evil in ignorance, then turn to Him soon. It is to these that God turns with mercy;" and 3) "God loves those who turn to Him in repentance and who are willing to purify themselves." The Qur'an evidently speaks of repentance and reform not just as an available option but of positive encouragement in their favour.

These Qur'anic guidelines are not confined to either the hudud, qisas or $t a$ 'zir. They apply to all of them but go beyond to provide the ingredients of a comprehensive philosophy of punishment. What is expounded, in other words, is a dynamic philosophy and outlook which can relate more meaningfully to contemporary realities than the juristic doctrines of fiqh that have moved in questionable directions.

The Qur'anic outlook on punishment may thus be characterised by its emphasis on retribution, deterrence, and reform. Yet the conventional fiqhi approach to 
punishments has fallen short of adequately reflecting the totality of Qur'anic guidance on this subject. Adding rehabilitation and reform to the philosophy of shariah punishments is not only scripturally justified but is tantamount also to acknowledging that crime is not a totally isolated phenomenon and that the society has increasingly become an unwilling partner in the rising tide of criminality and aggression. It is also important for the society to see that juridical issues are addressed in their proper context in the hope of finding well-moderated responses to them. The question is what should come first, implementing punishments or justice? And what is the higher purpose of shariah and ultimate goals of those punishments? To ignore this order of priorities is one of the problems encountered in the manner Islamic punishments are understood and applied.

In a case of theft that arose at the time of the second caliph 'Umar b. alKhattab, a young offender was charged with theft and the charge was proven, but before the punishment was carried out, the mother of the convict asked the caliph: "Pardon him O Commander of the Faithful, for it was his first time." The mother pleaded with the caliph that her son had shown remorse and wanted to do good. The caliph granted the plea and said "God is too merciful to reveal the nakedness of his servant for his first failure." 10 This was, of course, before the scholastic accretions began to erode the pioneering spirit of that precedent and approach.

\section{Fiqh and Contemporary Opinion}

The leading schools of Islamic law have ruled that repentance is only valid in the hudud offences when it is attempted before the offence is completed and before it is reported to the authorities. Once it is reported and action is taken, there is no room whatsoever for repentance. This is tantamount to imposing an unwarranted juristic limitation on the more versatile language of the Qur'an. Muslim jurists may have had their reasons, deemed suitable perhaps for their time, but if a suitable opportunity arises in a stressing case, then no juristic restrictions should stand in the way of the more open, indeed encouraging, approach of the Qur'an to repentance, self-emendation and reform. Moreover, if repentance were to have a meaningful role in the legal proceedings of the hudud, that role must surely not be confined to inchoate crimes nor only to the pre-trial stage, but should logically be extended to the entire length of criminal proceedings, before and even after prosecution and trial. This would necessarily mean a change in the conventional perceptions of the hudud, a transition, that is, from the mandatory enforcement of fixed penalties to a penal policy that is duly cognisant of the importance of the Qur'anic vision and provides opportunity and space for its due 
implementation. The prescribed punishments in the sense of fixed upper limits can still be observed as an integral part of this approach.

A likely explanation as to why rehabilitation and reform do not find a suitable place in the fiqh blueprint of hudud may be that pre-modern penal systems were ill-equipped to integrate the more versatile Qur'anic dispensations into their working modalities, hence their exclusive focus on fixed penalties and an overly punitive approach to the subject. But those conditions have changed, and new varieties of penal sentences, such as probation orders, suspended sentence, house arrest, community service, etc., are now available, in addition to caning and imprisonment, which should be utilised in a revised Islamic theory of punishment.

The renowned Shaykh Yusuf al-Qaradawi (b.1926) has underscored the many temptations that modern society has created for criminality and aggression. With regard to the punishment of adultery he wrote: when there is a dramatic change of circumstances, when the door to halal is closed and one thousand doors to haram are opened, the individual is surrounded by temptations to sin. Is it then certain that justice will be served by insisting on the hadd of adultery? ${ }^{11}$ With regard to the punishment of theft, al-Qaradawi also observed:

The justice of Islam does not admit the logic that the command of God is executed on the thief as punishment for what he or she might have stolen and yet we neglect the command of God on the payment of zakah and the social support system of Islam. There is only one verse in the Qur'an on the punishment of theft but literally dozens of verses on zakah and helping the poor. ${ }^{12}$

The prominent Syrian jurist, Mustafa Ahmad al-Zarqa (d.1999), observed that the prevailing environment is unsuitable for the enforcement of hudud. He then invokes the Islamic legal maxim that "necessity makes the unlawful permissible." Al-Zarqa added: when emergency or unavoidable situations hinder the enforcement of an obligatory command, then the latter may be temporarily postponed. He then concluded that the hudud may be substituted with alternative punishments until such a time when conditions are right for their proper enforcement. ${ }^{13}$

Shaykh 'Abd Allah bin Bayyah (b.1935) explains that shariah and religion are two distinct but separate aspects of Islam. Whereas religion is primarily about dogma and faith, shariah consists of practical rules. Faith is founded on decisive proof of the Qur'an and mutawatir (continuous testimony) hadith, whereas the practical rules stand on effective causes and conditions. Neglecting practical rules does not amount to renunciation of Islam provided it is not espoused 
with rejection or denial in principle. Hudud fall under the practical rules and they depend on their effective causes, and are enforced only when their causes and conditions are present. Bin Bayyah also sees the prevailing conditions in the Muslim world as imbued with doubts of different kinds brought about by secularist modernity, and should be addressed through sustained enlightenment efforts before implementing the hudud. Bin Bayyah concludes that hudud may be suspended if enforcement means that greater harm will definitely materialise. ${ }^{14}$

Fazlur Rahman (d.1988) observed that the Qur'anic concept of hudud, which stands for 'separating or preventing,' has been reduced, by virtue of later developments, to fixed and unchangeable punishment. If one were to apply the basic concepts of deterrence, rehabilitation and reform in the interest of striking a balanced approach to punishment one would not only have observed the original outlook of the Qur' an but avoided in the meantime a great deal of inconsistency and confusion which should not have arisen in the first place. ${ }^{15}$

In sum there is a marked difference between the finely blended outlook of the Qur'an on punishment and the later juristic additions that narrowed it down to fixed punishments. It is unfortunately the latter that has dominated judicial practice. Imitation (taqlid) is still quite strong such that it would take a degree of intellectual originality and rigour to bring about meaningful change by reconnecting with the original Qur'anic vision on hudud and Islamic criminal laws.

\section{Hudud in Malaysia}

Most of the hudud-related debates underline the wider question of justice in that a literal application of these punishments, which is usually the case, may actually not secure justice and even lead to oppression. Justice is the cardinal objective of all punishments in Islam. It is an emphatic obligation, in the first place, of the rulers to implement. All Muslims are enjoined to be just, even to their enemies, and "even if it be against yourselves, your parents and relatives" (al-Nisa", 4:135). Then there is the parallel concern as to whether enforcing the hudud as an isolated case in an otherwise predominantly secular legal system and state can actually serve their desired purposes. In multi-religious societies, such as Malaysia, questions are also asked over the status of non-Muslims, and due observance of the constitutional principle of legality in crimes and punishments. Leading twentieth-century scholars in many Muslim countries have recognised these concerns and advised that hudud punishments should not be applied under doubtful situations and when they lead to oppressive consequences. In such situations, they have advised suspension and substitution of the hudud with other modes of punishment. 
These positions have been known for many decades. Yet there is a disconnect, in the case of Malaysia particularly, with outside Islamic scholarship. The proponents of hudud in Malaysia have virtually ignored ijtihad-oriented developments in the Muslim world, and insisted instead on implementing a version of the hudud that does not stand the test of scrutiny. And worst still, instead of turning to bridge the yawning gap between the law and social reality and address the challenges, hudud proponents engage in exaggerations. Hudud are often made out to be the paramount indicators of the Islamic identity of states and societies. To measure the Islamicity of a state or a community of believers by reference to a set of punishments is not only reductionist but tantamount to judging Islam by one of its unwanted elements. Punishment of any kind is rather remote from the spiritual core of Islam. Yet exaggerations about the hudud unfortunately prevail among Muslims in this country and, in various degrees, also in many other Muslim countries.

The obsession with hudud and shariah punishments has also diverted the attention of the Muslim ummah from those fundamental values and principles that endowed strength and dynamism to Islamic civilisation in its heyday. Apart from justice, the passion for knowledge was the driving force behind Islam's much acclaimed role between the ninth and fourteenth centuries A.D. Muslim scientists drew motivation from the repeated Qur'anic emphasis on the quest for truth, rational enquiry and observation. How to enhance the pursuit of knowledge and science, establish good governance, and fight poverty and corruption within the ummah, rather than the implementation of hudud, should be among the priorities for today's Muslims. Official corruption is a scourge that debilitates most Muslim countries and their governments from the due fulfilment of their duties. Good governance becomes a utopia in the face of rampant corruption. Combating Malaysia's most recent experience with widespread corruption under Najib Razak's veritable kleptocracy is the biggest challenge of the Pakatan Harapan government since it came into power in May 2018. The 1MDB corruption scandal has become a long-running saga of unbelievable scale, and the single most burdensome preoccupation of the $\mathrm{PH}$ government under Tun Mahathir Mohamad. The conventional understanding of hudud would be difficult to relate to this kind of corruption, unless they are understood in its Qur'anic sense, as violation of God-ordained limits, in which case hudud could well subsume corruption, and fasad fi'l-ard (spreading of corruption in the earth) as also expounded in the Qur'an.

Part of the explanation as to why hudud proponents in Malaysia have ignored realities in Kelantan and the rest of Malaysia lies in their narrow, superficial notion of linking Malay ethnicity with their Islamic identity. But what defines the identity of Islam in the Qur'an is not ethnicity at all, but a profound commitment 
to justice, compassion and human dignity firmly rooted in God-Consciousness and faith.

\section{Conclusion and Recommendations}

The foregoing analysis offers a fresh interpretation of the hudud laws, which have proven difficult to implement for a very long time. Yet Muslim scholars and ulama have stopped short of a fresh reconstruction of the hudud on the assumption that they are based in the clear text of the Qur'an, and must therefore be taken at face value. Our position in attempting a fresh interpretation is founded on the premise that the text needs to be taken in its entirety and properly understood in the first place. This is what we have attempted here.

Should our reconstruction of the hudud laws be granted acceptance and duly implemented, it would help rid the hudud of unwarranted rigidities and open them to judicial discretion to ascertain the veracity of repentance through observation of the personal conditions of the offender and other relevant factors. The hudud would, in other words, no longer be fixed and mandatory and it would be possible for the judge to look into the surrounding circumstances of the case, and when satisfied of the veracity of repentance and sincerity of the offender to correct his or her conduct, the judge would act on that basis and impose a lesser punishment, or even substitute the prescribed punishment, say of theft, with another appropriate substitute.

We conclude this paper with the following recommendations:

- The conventional reading of the Qur'an on hudud laws ignores and leaves out the Qur'anic directives on repentance and reform. A more holistic reading of the Qur'an, as proposed above, is therefore called for and should be attempted to advance a fresh understanding of the Qur'an that would lead to fundamental reform of the hudud laws.

- The conventional fiqh theory of hudud in Islamic law has become a black letter that lawyers and judges find difficult to apply, simply because it is rigidified and severe. It therefore needs to be revised in accordance with a fuller and more comprehensive reading of the Qur'an.

- Understanding by itself is not enough unless it leads to the desired action. In view of the fact that the hudud are a sensitive subject, Muslim ulama and politicians show reluctance to be proactive. This is unhelpful; a degree of moral courage and initiative will be necessary to take the 
fresh understanding of the subject before us to its rightful conclusions, preferably through new legislation.

- $\quad$ Existing court procedures on hudud punishments also need to be revised and changed so as to allow space for considering the surrounding circumstances of the case, including the conditions of the offender, and the possibility of repentance and reform prior to sentencing.

\section{Notes}

* Mohammad Hashim Kamali, Founding CEO of IAIS Malaysia, graduated from Kabul University, and then obtained his PhD in Islamic and Middle Eastern Law at the University of London in 1976. He served as Professor of Islamic Law and Jurisprudence at the International Islamic University Malaysia (1985-2004), then Dean of the International Institute of Islamic Thought and Civilization (ISTAC) from 2004-2006. He was Assistant Professor at McGill University's Institute of Islamic Studies; Visiting Professor at Capital University, Ohio; and the Wissenschaftskolleg, Berlin. He was a member of the Constitution Review Commission of Afghanistan (2003), and a UN shariah expert on the constitutions of Iraq, the Maldives and Somalia (2004-2005). He has published over 200 academic articles and 35 books. He can be contacted at ceo@iais.org.my.

1. Cf. Fazlur Rahman, 'The Concept of Hadd in Islamic Law,' Islamic Studies 4 (1965): 237; Kassim Ahmad, 'Resolving the 'Hudud' Law Dilemma,' New Straits Times, 4 December 1993, 13.

2. Sahih al-Bukhari, $6^{\text {th }}$ ed., vol. 3, trans. Muhsin Khan (Lahore: Kazi Publication, 1982), 512, hadith no. 778 .

3. Abu 'Isa Muhammad al-Tirmidhi, Sunan Al-Tirmidhi, vol. 2 (Beirut: Dar al-Fikr 1980/1400), hadith no. 1447.

4. Al-Shura, 42:40.

5. Al-An'am, 6:164.

6. Cf., Al-Nahl, 16:90.

7. Al-Nahl, 16:126, and Al-Baqarah, 2:194.

8. Al Nisa', 4:17.

9. Al-Baqarah, 2:222.

10. See for detail Muhammad Abu Zahrah, Al-Jarimah Wa'l 'Uqubah fi'l-Fiqh alIslami: al-'Uqubah, $10^{\text {th }}$ ed, ed. Muhiyuddin Fathi al-Shaludi (Cairo: Dar al-Fikr al-'Arabi, 2006), 134-6.

11. Yusuf Al-Qaradawi, Shari'ah al-Islam Salihah li’l-Tatbiq fi Kull Zaman wa Makan (Cairo: Dar al-Sahwah, 1393/1972), 162.

12. Ibid.

13. Mustafa Ahmad a1-Zarqa, A1-Madkhal al-Fiqhi al- 'Aam, vol. 1 (Damascus: Dar al-Fikr, 1968/1387), 51 .

14. 'Abd Allah bin al-Mafuz bin Bayyah, Tanbih al-Waqi' 'ala Ta'sil Fiqh al-Waqi' (UAE: al-Majlis al-Watani li'l-I'lam, 2014), 82-9. 
15. Cf. Fazlur Rahman, 'The Concept of Hadd,' 248-50. 